\title{
Risk factors associated with postpartum subclinical hypocalcemia in dairy cows
}

\author{
R. C. Neves, ${ }^{*}$ B. M. Leno, $†$ T. Stokol, ${ }^{*}$ T. R. Overton, $†$ and J. A. A. McArt ${ }^{\star 1}$ \\ *Department of Population Medicine and Diagnostic Sciences, College of Veterinary Medicine, and \\ †Department of Animal Science, Cornell University, Ithaca, NY 14853
}

\begin{abstract}
Our study objectives were to evaluate the association of prepartum plasma $\mathrm{Mg}$ concentrations with subclinical hypocalcemia $(\mathrm{SCH})$ classification at parturition and to evaluate the association of other cow-level risk factors with $\mathrm{SCH}$ classification at calving or at $2 \mathrm{~d}$ in milk (DIM). A total of 301 animals from 2 dairy herds located in New York were enrolled in a cohort study. Blood samples were collected at approximately $1 \mathrm{wk}$ before the expected calving date, within $4 \mathrm{~h}$ of calving, and at 2 DIM. Prepartum samples had plasma macromineral concentrations $(\mathrm{Ca}, \mathrm{K}, \mathrm{Mg}, \mathrm{P})$, albumin, and $\beta$-hydroxybutyrate analyzed. Samples collected at calving were analyzed for $\mathrm{Ca}$ only, and samples from 2 DIM had macromineral and albumin concentrations determined. Postpartum SCH was defined as $\mathrm{Ca}$ concentrations $\leq 2.1 \mathrm{mmol} / \mathrm{L}$. The prevalence of $\mathrm{SCH}$ at calving was 2,40 , and $66 \%$ for first, second, and third or greater parities, respectively. Only $4 \%$ of cows could be classified with prepartum subclinical hypomagnesemia ( $\mathrm{Mg}$ concentrations $<0.8 \mathrm{mmol} / \mathrm{L})$, which did not provide enough power to appropriately determine the association of plasma $\mathrm{Mg}$ with postpartum Ca concentrations and its effect on SCH classification. Multiparous cows with Ca concentrations $\leq 2.4 \mathrm{mmol} / \mathrm{L}$ in the prepartum period and third or greater parity cows had a higher risk of being categorized as $\mathrm{SCH}$ at calving [relative risk $(\mathrm{RR})=1.4$ and 1.7 , respectively]. The risk of SCH at 2 DIM was associated with the interaction of $\mathrm{Ca}$ status at calving and lameness score. Nonlame cows with Ca concentrations $\leq 2.1 \mathrm{mmol} / \mathrm{L}(\mathrm{RR}=3.2)$ and normocalcemic lame cows at parturition $(\mathrm{RR}=$ 3.4) were more likely to be SCH at 2 DIM compared with nonlame normocalcemic cows. In conclusion, we identified a prepartum Ca cut-point for identification of cows that are more likely to be classified as $\mathrm{SCH}$ at calving. Different risk factors were associated with
\end{abstract}

Received September 7, 2016.

Accepted January 24, 2017.

${ }^{1}$ Corresponding author: jmcart@cornell.edu
SCH depending on the timing of diagnosis relative to parturition.

Key words: dairy cow, subclinical hypocalcemia

\section{INTRODUCTION}

Advances in dairy cattle nutrition and management have significantly minimized dietary macromineral imbalances capable of causing clinical deficiencies. However, subclinical disorders still influence dairy cow health and performance, as the hormonal and metabolic adaptations associated with the dry period and the onset of lactation can influence macromineral homeostasis. Subclinical hypocalcemia (SCH) has been demonstrated to be a prevalent condition across herds in the United States (Reinhardt et al., 2011), urging scientists to better define risk factors associated with this condition to optimize preventative strategies.

Blood Ca concentrations reach a nadir at approximately 12 to $24 \mathrm{~h}$ after calving (Goff, 2008), with animals that are more predisposed to metritis having the lowest concentrations between 24 and $48 \mathrm{~h}$ after parturition (Martinez et al., 2012). Thus, SCH classification might be dependent on the timing of sampling relative to parturition. The risk factors associated with $\mathrm{SCH}$ relative to the timing of diagnosis have not yet been elucidated, and studies on the topic are warranted.

Prevention of hypocalcemia is largely focused on dietary means, in which restriction of cations (mainly sodium and potassium) with or without addition of anions in the close-up diet are often employed (NRC, 2001). For the periparturient cow, Mg status also has a major effect on Ca metabolism. Hypomagnesemia is a well-known risk factor for clinical hypocalcemia (Sansom et al., 1983; Lean et al., 2006), and lower prepartum dietary $\mathrm{Mg}$ levels are implicated in lower $\mathrm{Ca}$ mobilization rates at parturition (van de Braak et al., 1987). In addition, parathyroid hormone secretion and 1,25-dihydroxyvitamin D metabolism have been shown to be impaired in Mg-depleted individuals (Fatemi et al., 1991). Therefore, $\mathrm{Mg}$ is often implicated as a contributor to $\mathrm{SCH}$; however, the contribution of lower 
prepartum plasma $\mathrm{Mg}$ concentrations as a risk factor for $\mathrm{SCH}$ has not yet been quantified in an observational trial.

Our first objective was to study the association of prepartum plasma $\mathrm{Mg}$ concentrations with the risk of cows being classified as $\mathrm{SCH}$ at parturition. In addition, we aimed to determine if different risk factors are associated with SCH diagnosis depending on the timing of blood sampling relative to calving.

\section{MATERIALS AND METHODS}

\section{Study Population}

The study was carried out on 2 dairy herds located in Cayuga County, New York, from April 28 until August 20, 2015 (herd A), and July 16 until November 11, 2015 (herd B). Farm enrollment criteria included a herd size equal or greater than 1,000 lactating cows, participation in monthly DHIA testing, and on-farm recording of animal health, production, and reproduction events. The study was approved by the Cornell University Institutional Animal Care and Use Committee (protocol 2014-0171). Herd A milked 1,475 cows 3 times/d and averaged $38.5 \mathrm{~kg} / \mathrm{d}$ of milk per cow. Herd B milked 1,700 cows 3 times/d until approximately 140 DIM, then 2 times/d until dry off, and averaged $37 \mathrm{~kg} / \mathrm{d}$ of milk per cow.

Animals were housed in freestall barns with concrete floors and fed a TMR in both herds. Samples of prepartum and postpartum rations were collected weekly and frozen. At the end of the trial, samples were dried at $55^{\circ} \mathrm{C}$ for $48 \mathrm{~h}$ and ground through a $2-\mathrm{mm}$ Wiley mill (Thomas Scientific, Swedesboro, NJ). In herd A, samples were composited over the duration of the study. In herd B, 2 composites of the prepartum rations were created to represent diets fed before and after removal of supplemental anions that occurred partway through the enrollment period. Samples were submitted to a commercial laboratory (Cumberland Valley Analytical Services, Hagerstown, MD) for wet chemistry analysis with methods as described by McCarthy et al. (2015b). Average diet composition and chemical analyses for prepartum and postpartum diets of both herds on a DM basis are presented in Table 1 .

\section{Study Design and Data Collection}

A retrospective cohort study was performed as part of a larger randomized clinical trial, in which cows were randomly allocated at calving to either a treatment group with oral Ca supplementation or a control group with no treatment intervention. For this observational study, only cows assigned to the control group were eligible for inclusion. A sample size of 295 total cows was estimated based on a $25 \%$ prevalence of prepartum subclinical hypomagnesemia and at least a $20 \%$ difference in $\mathrm{SCH}$ incidence between the normomagnesemic (unexposed) and the subclinically hypomagnesemic (exposed) groups for a study with $80 \%$ power and a $5 \%$ significance level. Calculations were performed using OpenEpi version 3.01 (OpenEpi, Atlanta, GA).

Animals had a blood sample collected within $4 \mathrm{~h}$ of calving, which was performed by trained farm personnel. Cows were excluded if they had a Ca treatment in the first 2 DIM $(\mathrm{n}=13)$, as timing of treatment relative to sampling could not be determined. Study personnel visited each herd daily at the same time of the day. Locomotion scoring was performed at 3 DIM by the first author for all animals in the study on a 1 to 5 scale (Sprecher et al., 1997).

Blood was sampled from each cow via puncture of the coccygeal vessels into lithium heparin vacutainer tubes (Greiner Bio-One, Monroe, NC) once weekly starting at approximately $260 \mathrm{~d}$ of gestation, within $4 \mathrm{~h}$ of calving, and at 2 DIM. Prior to the start of the study, macromineral stability of unseparated bovine blood samples was determined to be dependent on the temperature of transportation when delayed blood separation occurs. Potassium concentrations were overestimated in blood samples transported at $4^{\circ} \mathrm{C}$ and stable at $22^{\circ} \mathrm{C}$ (R. C. Neves and T. Stokol, unpublished results). No differences in $\mathrm{Ca}, \mathrm{Mg}$, and $\mathrm{P}$ concentrations were observed in samples transported at 4 or $22^{\circ} \mathrm{C}$. Given these results, blood samples were transported from the farm to Cornell University at $22^{\circ} \mathrm{C}$. At arrival, prepartum blood samples had BHB measured with the Precision Xtra meter (Abbott Laboratories, Lake Bluff, IL). Blood was then centrifuged at $1,000 \times g$ for $10 \mathrm{~min}$ at $22^{\circ} \mathrm{C}$ and plasma harvested and stored at $-80^{\circ} \mathrm{C}$ within $6 \mathrm{~h}$ of collection for later macromineral analysis.

At study completion, the plasma samples collected at approximately 1 wk before parturition (range of 4 to 10 $\mathrm{d}$ before calving, with a median of $7 \mathrm{~d}$ ), within $4 \mathrm{~h}$ of calving, and at 2 DIM were submitted to the New York State Animal Health and Diagnostic Laboratory (Ithaca) for measurement of macrominerals and albumin. For prepartum and 2 DIM samples, total $\mathrm{Ca}, \mathrm{Mg}, \mathrm{K}$, $\mathrm{P}$, and albumin concentrations were measured, whereas only total Ca was measured on samples collected within $4 \mathrm{~h}$ of parturition. All biochemical tests were done on a high-throughput automated analyzer (Hitachi Modular P800, Roche Diagnostics, Indianapolis, IN) with reagents from Roche Diagnostics. Controls were assayed daily according to manufacturer's recommendations to ensure appropriate method performance. 
NEVES ET AL.

Table 1. Ingredients and chemical composition of the prepartum and postpartum diets

\begin{tabular}{|c|c|c|c|c|c|}
\hline \multirow[b]{3}{*}{ Item } & \multicolumn{3}{|c|}{ Prepartum } & \multicolumn{2}{|c|}{ Postpartum } \\
\hline & \multirow[b]{2}{*}{ Herd A } & \multicolumn{2}{|c|}{ Herd B } & \multirow[b]{2}{*}{ Herd A } & \multirow[b]{2}{*}{ Herd B } \\
\hline & & Period $1^{1}$ & Period $2^{1}$ & & \\
\hline \multicolumn{6}{|l|}{ Ingredient (\%; DM basis) } \\
\hline Corn silage & 51.40 & 39.81 & 37.18 & 38.08 & 40.96 \\
\hline Haylage & - & 22.48 & 20.37 & 10.50 & 11.50 \\
\hline Dry hay & 22.35 & - & - & 0.53 & 2.37 \\
\hline Wheat straw & - & 9.24 & 8.50 & - & - \\
\hline Ground corn grain & 6.90 & - & 1.13 & 19.58 & 8.77 \\
\hline Canola meal & 6.21 & 6.92 & 6.50 & 9.38 & 5.81 \\
\hline Soybean meal & - & - & - & 1.15 & 1.95 \\
\hline Bloodmeal & 2.53 & 1.03 & 0.95 & 0.86 & 1.57 \\
\hline Whole cottonseed & - & - & - & 6.15 & - \\
\hline Wet brewers grains & - & - & - & 4.03 & - \\
\hline Citrus pulp & - & - & - & - & 5.28 \\
\hline Distillers grains & - & 1.84 & 7.84 & - & 3.88 \\
\hline Corn germ meal & - & 3.12 & 3.69 & - & 4.09 \\
\hline Corn gluten feed & - & - & - & 0.86 & - \\
\hline Soybean hulls & 0.07 & - & 5.03 & - & 3.20 \\
\hline Wheat middlings & 0.07 & - & - & 1.20 & 3.55 \\
\hline Bakery or chocolate by-product & - & 7.21 & 3.93 & - & 1.39 \\
\hline SoyPlus $^{2}$ & 1.08 & - & - & 1.60 & - \\
\hline SoyChlor $^{2}$ & - & 4.07 & - & - & - \\
\hline Amino Plus ${ }^{3}$ & - & - & - & - & 0.52 \\
\hline Urea & 0.12 & - & - & 0.53 & 0.53 \\
\hline Lactose & - & - & 1.93 & - & 0.26 \\
\hline Dextrose & - & 0.27 & - & - & - \\
\hline Molasses & - & 0.78 & - & - & 0.52 \\
\hline BioChlor $^{4}$ & 1.21 & - & - & - & - \\
\hline Animate $^{5}$ & 2.02 & - & - & - & - \\
\hline Calcium sulfate & 0.40 & 0.98 & 0.64 & - & - \\
\hline Magnesium sulfate & 0.40 & - & - & - & - \\
\hline Magnesium oxide & - & 0.12 & 0.32 & 0.11 & 0.12 \\
\hline $\operatorname{Min}-\mathrm{Ad}^{6}$ & 0.80 & - & - & 0.45 & \\
\hline Commercial AA supplements & & & & 0.26 & 0.12 \\
\hline Commercial fat supplements & - & - & 0.85 & 0.85 & 1.22 \\
\hline Vitamins, minerals and additives & 4.33 & 2.13 & 1.17 & 3.85 & 2.39 \\
\hline Rumensin ${ }^{7}$ & 0.12 & 0.009 & - & 0.04 & 0.007 \\
\hline \multicolumn{6}{|l|}{ Chemical analysis (\%; DM basis) } \\
\hline Starch & 22.1 & 15.7 & 17.5 & 25.2 & 20.5 \\
\hline $\mathrm{CP}$ & 14.3 & 15.2 & 14.2 & 17.4 & 16.3 \\
\hline Fat & 3.22 & 4.73 & 4.47 & 5.72 & 4.64 \\
\hline NFC & 35.2 & 31.1 & 33.3 & 37.0 & 39.6 \\
\hline NDF & 40.4 & 40.8 & 43.2 & 34.1 & 34.4 \\
\hline $\mathrm{ADF}$ & 26.8 & 27.9 & 28.5 & 22.1 & 22.6 \\
\hline Lignin & 4.18 & 4.64 & 4.42 & 3.69 & 3.88 \\
\hline $\mathrm{Ca}$ & 1.78 & 1.48 & 0.86 & 1.09 & 1.03 \\
\hline $\mathrm{P}$ & 0.40 & 0.39 & 0.38 & 0.44 & 0.40 \\
\hline $\mathrm{Mg}$ & 0.45 & 0.39 & 0.36 & 0.37 & 0.28 \\
\hline $\mathrm{K}$ & 1.12 & 1.81 & 1.49 & 1.37 & 1.36 \\
\hline $\mathrm{Cl}$ & 0.63 & 0.77 & 0.39 & 0.57 & 0.54 \\
\hline $\mathrm{Na}$ & 0.18 & 0.12 & 0.12 & 0.45 & 0.46 \\
\hline $\mathrm{S}$ & 0.41 & 0.36 & 0.29 & 0.29 & 0.25 \\
\hline $\mathrm{NE}_{\mathrm{L}}(\mathrm{Mcal} / \mathrm{kg})$ & 1.50 & 1.52 & 1.59 & 1.70 & 1.65 \\
\hline $\mathrm{DCAD}^{8}(\mathrm{mEq} / 100 \mathrm{~g}$ of $\mathrm{DM})$ & -6.9 & 7.3 & 14.1 & 20.9 & 23.7 \\
\hline
\end{tabular}

${ }^{1}$ For herd B, period 1 represents the prepartum diet from the start of the study until September 21, 2015, when the diet was supplemented with anionic salts. Period 2 represents the prepartum diet from September 22, 2015, until the end of the study, during which supplemental anions were no longer supplemented in the diet.

${ }^{2}$ West Central, Ralston, IA.

${ }^{3} \mathrm{Ag}$ Processing Inc., Omaha, NE.

${ }^{4}$ Church \& Dwight Co. Inc., Princeton, NJ.

${ }^{5}$ Phibro Animal Health Corp., Quincy, IL.

${ }^{6} \mathrm{MIN}-\mathrm{AD}$ Inc., Winnemucca, NV.

${ }^{7}$ Elanco Animal Health, Greenfield, IN.

${ }^{8}$ Calculated as $[(\mathrm{Na} \%$ of DM/0.023) $+(\mathrm{K} \%$ of DM/0.039) $]-[(\mathrm{S} \%$ of DM/0.016) $+(\mathrm{Cl} \%$ of DM/0.0355) $]$. 


\section{Statistical Analyses}

All statistical analyses were performed in SAS version 9.4 (SAS Institute Inc., Cary, NC). Descriptive statistics were performed using the FREQ and MEANS procedure. Postpartum SCH was defined as a plasma concentration $\leq 2.1 \mathrm{mmol} / \mathrm{L}(8.4 \mathrm{mg} / \mathrm{dL}$; Chapinal et al., 2012).

Effect of Prepartum Plasma Mg Concentrations with $S C H$ at Parturition. A receiver operating characteristic (ROC) curve was built using the LOGISTIC procedure to determine whether $\mathrm{Mg}$ concentrations in the prepartum period were associated with $\mathrm{SCH}$ at calving and whether different cut-points could better discriminate the outcome. Prepartum subclinical hypomagnesemia was later classified as a plasma concentration $<0.8 \mathrm{mmol} / \mathrm{L}$ (Goff, 2008); this categorization was used to describe the prevalence of the condition in the cohort under study.

Risk Factors Associated with SCH Classification at Parturition and at 2 DIM. The outcomes of interest were the likelihood of cows being classified as SCH at parturition (i.e., blood sampling performed within $4 \mathrm{~h}$ of calving) or at 2 DIM. Parity was divided into first, second, and third or greater lactations, and prepartum BHB categorized into $<0.6$ and $\geq 0.6$ $\mathrm{mmol} / \mathrm{L}$ (Tatone et al., 2015). As SCH at calving was a rare event for primiparous animals $(\mathrm{n}=2)$, they were removed from further analyses. Locomotion scoring was considered as a categorized predictor for both outcomes (i.e., scores 1 and 2 as normal, 3 or higher as lame). We assumed the locomotion score collected at 3 DIM was representative of the locomotion score 1 wk before calving. Calving difficulty was classified as 0 (small to no assistance) or 1 (dystocia). Twinning and stillbirth were also considered as predictors.

For the biochemical results, prepartum total $\mathrm{Ca}, \mathrm{Mg}$, $\mathrm{K}$, $\mathrm{P}$, albumin, and BHB concentrations were considered as potential predictors of $\mathrm{SCH}$ in the postpartum. For both models, continuous variables (prepartum $\mathrm{Ca}$, $\mathrm{Mg}, \mathrm{K}, \mathrm{P}$, and albumin) were checked for normality. Data categorization was performed whenever nonlinear distributions were identified for the different models. Each variable was examined for association with the outcomes of interest using contingency tables and the Chi-squared statistic for 2-level variables. Univariate logistic regression was used for continuous variables or categorical variables with more than 2 levels using the LOGISTIC procedure. All variables with a univariate association with the outcome at $P \leq 0.25$ were considered as covariates. Predictors were only considered in the continuous scale if they were normally distributed and had a linear association with the outcome of interest in the logit scale as determined by linear splines with 3 knots (Hosmer et al., 2013). Only prepartum P concentrations were considered in the continuous scale, whereas $\mathrm{Ca}, \mathrm{Mg}, \mathrm{K}$, and albumin were categorized into quartiles. The categorized prepartum $\mathrm{Ca}$ variable based on quartiles was significant in one of the models ( $\mathrm{SCH}$ at calving only), though it was recategorized to a dichotomous variable representing $\mathrm{Ca}$ concentrations $\leq 2.4 \mathrm{mmol} / \mathrm{L}(9.6 \mathrm{mg} / \mathrm{dL})$ or $>2.4 \mathrm{mmol} / \mathrm{L}$ in the final model to facilitate interpretation. The cut-point chosen was based on the threshold that maximized the sensitivity and specificity of the prediction as based on ROC analysis (area under the curve $=0.61$ ). Subclinical hypocalcemia classification at calving was considered as a predictor for the second model evaluating $\mathrm{SCH}$ at 2 DIM after the categorized variable representing prepartum Ca concentrations was determined not to be significant for this time point.

For both outcomes, Poisson models were fitted with the GENMOD procedure with a log link and Poisson distribution. Herd was treated as a fixed effect. A manual backward stepwise selection elimination process was used to build the final models. Variables that caused more than $20 \%$ change in the estimates of one or more predictors were retained as confounders. Herd and parity were considered confounders a priori and retained in the final models regardless of $P$-value. Pairwise interactions among all combinations of the predictors were tested in the final model and kept if significant $(P$ $\leq 0.05$ ). Goodness of fit tests based on deviance and Pearson Chi-squared statistics of the final models indicated model underdispersion. Therefore, relative risk estimates were adjusted for underdispersion by fitting a modified Poisson regression using robust error variances (Zou, 2004). All $P$-values reported are for type III analysis. Even though the prepartum ration was modified partway through the trial in herd $\mathrm{B}, \mathrm{SCH}$ incidence was not different between periods (i.e., before and after the ration change; $P=0.59)$. In addition, a 3-level categorical variable was created to test for the effect of the diet change on the overall model predictabilities. No changes on the final coefficients were observed if the variable was considered as 2-level (herd) or as 3-level (study period) in the final models. Thus, final models report herd as a 2-level variable.

\section{RESULTS}

In total, 301 animals were enrolled in the study (92 from herd A and 209 from herd B). First-lactation animals represented $35.5 \%(\mathrm{n}=104)$ of the population, whereas $28.0(\mathrm{n}=84)$ and $37.5 \%(\mathrm{n}=113)$ were in second and third or greater lactations, respectively. The total Ca results of 5 animals (2 primiparous and 




Figure 1. Distribution of plasma Ca concentrations collected within $4 \mathrm{~h}$ of parturition and at 2 DIM for 194 multiparous Holstein cows. Median and interquartile ranges (25th and 75th percentile) are overlaid at each time point.

3 multiparous) collected within $4 \mathrm{~h}$ of parturition were not included in the analysis due to severe hemolysis. Plasma Ca concentrations within 4 of parturition and at 2 DIM are presented in Figure 1. The prevalence of SCH at calving in the remaining 296 animals was 2 (2/102), 40 (34/84), and 66\% (73/110) for first, second, and third or greater parities, respectively. Plasma mac- romineral status for multiparous animals and by $\mathrm{SCH}$ classification at calving is reported in Table 2 .

\section{Plasma Mg Association with SCH at Parturition}

We found no association between prepartum Mg concentration and SCH classification at parturition. The

Table 2. Plasma macromineral status at approximately 1 wk prepartum, within $4 \mathrm{~h}$ of parturition, and at 2 DIM for all multiparous cows $(\mathrm{n}=194)$ enrolled in the study stratified as normocalcemic $(\mathrm{Ca}>2.1 \mathrm{mmol} / \mathrm{L}$; $\mathrm{n}=87$ ) or subclinically hypocalcemic $(\mathrm{SCH} ; \mathrm{Ca} \leq 2.1 \mathrm{mmol} / \mathrm{L} ; \mathrm{n}=107)$ based on a blood sample collected within 4 h of calving ${ }^{1}$

\begin{tabular}{|c|c|c|c|}
\hline Plasma analyte [mean (SD)] & $\begin{array}{l}\text { All multiparous } \\
\text { cows }\end{array}$ & Normocalcemic & $\mathrm{SCH}$ \\
\hline \multicolumn{4}{|l|}{ Prepartum (mmol/L, unless noted) } \\
\hline $\mathrm{Ca}$ & $2.44(0.12)$ & $2.46(0.09)$ & $2.42(0.14)$ \\
\hline $\mathrm{Mg}$ & $0.94(0.09)$ & $0.93(0.08)$ & $0.94(0.08)$ \\
\hline $\mathrm{K}$ & $4.26(0.29)$ & $4.30(0.27)$ & $4.24(0.30)$ \\
\hline $\mathrm{P}$ & $1.93(0.25)$ & $1.96(0.24)$ & $1.90(0.25)$ \\
\hline ВHB & $0.51(0.19)$ & $0.48(0.15)$ & $0.55(0.21)$ \\
\hline Albumin (g/dL) & $3.42(0.25)$ & $3.43(0.20)$ & $3.41(0.29)$ \\
\hline \multicolumn{4}{|l|}{ Within $4 \mathrm{~h}$ of parturition ${ }^{2}$} \\
\hline $\mathrm{Ca}(\mathrm{mmol} / \mathrm{L})^{\circ}$ & $2.05(0.25)$ & $2.25(0.11)$ & $1.88(0.21)$ \\
\hline \multicolumn{4}{|l|}{$2 \mathrm{DIM}$ (mmol/L, unless noted) } \\
\hline $\mathrm{Ca}$ & $2.10(0.25)$ & $2.18(0.23)$ & $2.03(0.26)$ \\
\hline $\mathrm{Mg}$ & $0.94(0.16)$ & $0.94(0.13)$ & $0.94(0.18)$ \\
\hline $\mathrm{K}$ & $4.24(0.35)$ & $4.25(0.29)$ & $4.23(0.39)$ \\
\hline $\mathrm{P}$ & $1.54(0.37)$ & $1.62(0.39)$ & $1.47(0.35)$ \\
\hline $\operatorname{Albumin}(\mathrm{g} / \mathrm{dL})$ & $3.25(0.28)$ & $3.26(0.26)$ & $3.26(0.29)$ \\
\hline
\end{tabular}

${ }^{1}$ First-parity animals are not included in the table due to their low incidence of SCH.

${ }^{2}$ Total Ca results from 3 multiparous animals were excluded from analysis due to hemolysis. 
area under the curve for the ROC was 0.51 (i.e., no discrimination). Only 13 animals (5 primiparous and 8 multiparous; $4 \%$ ) were classified as subclinically hypomagnesemic in the prepartum.

\section{Variables Associated with SCH Classification at Parturition}

Prepartum total Ca status, parity, and herd were significant predictors of $\mathrm{SCH}$ classification at calving (Table 3). Independent of parity, multiparous animals with blood Ca concentrations $\leq 2.4 \mathrm{mmol} / \mathrm{L}$ in the prepartum period were $40 \%$ more likely to be classified as $\mathrm{SCH}$ at parturition than cows with $\mathrm{Ca}$ concentrations $>2.4 \mathrm{mmol} / \mathrm{L}$. In addition, animals in their third or greater parities were $70 \%$ more likely to be classified as $\mathrm{SCH}$ than second-lactation animals. Cows in herd $\mathrm{B}$ were $50 \%$ more likely to be classified as $\mathrm{SCH}$ than animals in herd $\mathrm{A}$.

\section{Variables Associated with SCH Classification at 2 DIM}

Table 4 summarizes the final model evaluating the risk factors of SCH classification at 2 DIM. Parity was not a significant predictor of $\mathrm{SCH}$ classification at 2 DIM and diagnosis of a retained placenta had borderline importance. A locomotion score by Ca status at calving interaction was found in the final model. For normocalcemic animals at calving, being lame was associated with a 3.2-times increased risk of being diagnosed as $\mathrm{SCH}$ at $2 \mathrm{DIM}$ compared with nonlame normocalcemic cows. Nonlame $\mathrm{SCH}$ cows at calving had an increased risk for maintaining their SCH state at 2 DIM. Lameness and $\mathrm{SCH}$ at calving together were associated with a 3.4-times increased risk of SCH at 2 DIM when compared with nonlame normocalcemic cows.

\section{DISCUSSION}

The first objective of our study was to evaluate the association of prepartum plasma $\mathrm{Mg}$ concentrations on the risk of SCH classification at parturition. We found no association of prepartum plasma $\mathrm{Mg}$ concentrations with SCH; however, the low prevalence of prepartum subclinical hypomagnesemia most likely impaired our ability to find any association. Even though $\mathrm{Mg}$ might contribute to $\mathrm{SCH}$ in herds using lower $\mathrm{Mg}$ feeding rates or sources with poorer bioavailability, the adequate $\mathrm{Mg}$ feeding rates for both herds included in our trial may have impaired our ability to find any associations between both macrominerals. Lean et al. (2006) predicted a considerable reduction in the risk of clinical hypocalcemia by increasing $\mathrm{Mg}$ feeding rates from 0.3 to $0.4 \%$ DM. As discussed by Goff (2008), increased $\mathrm{Mg}$ in prepartum diets can lessen the occurrence of hypocalcemia due to $\mathrm{Mg}$ deficient states. Observational studies using herds that have a higher variability in plasma prepartum $\mathrm{Mg}$ concentrations are needed to better establish the potential contribution of subclinical Mg deficiency to SCH.

To our knowledge, this was the first study to evaluate risk factors associated with $\mathrm{SCH}$ classification at 2 different time points relative to calving. We found that different variables were associated with each outcome, indicating that the timing of blood sample collection for SCH classification is important. Prepartum cows with Ca concentrations $<2.4 \mathrm{mmol} / \mathrm{L}$ at approximately $1 \mathrm{wk}$ before calving had an increased risk of being classified as $\mathrm{SCH}$ at parturition. A few studies have established the importance of $\mathrm{SCH}$ as a risk factor for negative health and production outcomes, though categorization of SCH differs between them. Chapinal et al. (2012) demonstrated that cows with serum Ca concentrations $\leq 2.1 \mathrm{mmol} / \mathrm{L}$ at wk 1,2 , and 3 postpartum produced

Table 3. Final Poisson regression model evaluating risk factors associated with subclinical hypocalcemia classification within $4 \mathrm{~h}$ of parturition in 194 multiparous cows

\begin{tabular}{|c|c|c|c|c|c|}
\hline Parameter & Estimate & $\mathrm{SE}$ & $P$-value & $\mathrm{RR}^{1}$ & $95 \%$ CI \\
\hline \multicolumn{6}{|l|}{ Parity } \\
\hline 2 & $\operatorname{Ref}^{2}$ & - & - & - & - \\
\hline$\geq 3$ & 0.53 & 0.16 & $<0.001$ & 1.7 & 1.2 to 2.3 \\
\hline \multicolumn{6}{|l|}{ Herd } \\
\hline A & Ref & - & - & - & - \\
\hline B & 0.40 & 0.18 & 0.02 & 1.5 & 1.1 to 2.1 \\
\hline \multicolumn{6}{|l|}{ Prepartum Ca } \\
\hline$>2.4 \mathrm{mmol} / \mathrm{L}$ & Ref & - & - & - & - \\
\hline$\leq 2.4 \mathrm{mmol} / \mathrm{L}$ & 0.33 & 0.12 & 0.001 & 1.4 & 1.1 to 1.8 \\
\hline
\end{tabular}


Table 4. Final Poisson regression model evaluating risk factors associated with subclinical hypocalcemia classification (SCH) at 2 DIM in 194 multiparous cows

\begin{tabular}{|c|c|c|c|c|c|}
\hline Parameter & Estimate & $\mathrm{SE}$ & $P$-value & $\mathrm{RR}^{1}$ & $95 \% \mathrm{CI}$ \\
\hline \multicolumn{6}{|l|}{ Parity } \\
\hline 2 & $\operatorname{Ref}^{2}$ & - & - & - & - \\
\hline$\geq 3$ & 0.14 & 0.18 & 0.42 & 1.1 & 0.8 to 1.6 \\
\hline \multicolumn{6}{|l|}{ Herd } \\
\hline $\mathrm{A}$ & Ref & - & - & - & - \\
\hline B & 0.13 & 0.20 & 0.52 & 1.1 & 0.8 to 1.7 \\
\hline \multicolumn{6}{|l|}{ Retained placenta } \\
\hline No & Ref & - & - & - & - \\
\hline Yes & 0.42 & 0.19 & 0.06 & 1.5 & 1.0 to 2.2 \\
\hline \multicolumn{6}{|l|}{ Locomotion score } \\
\hline Not lame & Ref & - & - & - & - \\
\hline Lame & 1.15 & 0.37 & 0.006 & - & - \\
\hline \multicolumn{6}{|l|}{$\mathrm{SCH}$ at parturition } \\
\hline $\mathrm{No}(\mathrm{Ca}>2.1 \mathrm{mmol} / \mathrm{L})$ & Ref & - & - & - & - \\
\hline Yes $(\mathrm{Ca}<2.1 \mathrm{mmol} / \mathrm{L})$ & 1.22 & 0.35 & $<0.001$ & - & - \\
\hline \multicolumn{6}{|c|}{ Locomotion score $\times \mathrm{SCH}$ at parturition } \\
\hline $\mathrm{Ca}>2.1 \mathrm{mmol} / \mathrm{L}$ and not lame & Ref & - & - & - & - \\
\hline $\mathrm{Ca}>2.1 \mathrm{mmol} / \mathrm{L}$ and lame & 1.15 & 0.37 & 0.002 & 3.2 & 1.5 to 6.5 \\
\hline $\mathrm{Ca} \leq 2.1 \mathrm{mmol} / \mathrm{L}$ and not lame & 1.17 & 0.37 & 0.001 & 3.2 & 1.6 to 6.5 \\
\hline $\mathrm{Ca} \leq 2.1 \mathrm{mmol} / \mathrm{L}$ and lame & 1.22 & 0.35 & $<0.001$ & 3.4 & 1.7 to 6.7 \\
\hline
\end{tabular}

${ }^{1}$ Relative risk.

${ }^{2}$ Reference category (i.e., the value to which the variable-level is being compared while controlling for the effect of the other predictors in the model).

$2.6,4.8$, and $7.1 \mathrm{~kg}$ less of milk per day, respectively, when compared with normocalcemic animals. Martinez et al. (2012) categorized SCH based on the lowest Ca concentration among 4 serum samples collected at 0 to 3 DIM using a cut-point $<2.15 \mathrm{mmol} / \mathrm{L}$ and found that $\mathrm{SCH}$ cows were more likely to develop metritis. Our results combined with those of previous studies suggest that both the timing of SCH diagnosis and the threshold used for $\mathrm{SCH}$ classification are important descriptors of the disease.

Differences in prepartum diets between the studied herds can help explain the increased risk of $\mathrm{SCH}$ classification at calving for herd $\mathrm{B}$. Herd A was feeding a lower DCAD diet, whereas herd $\mathrm{B}$ fed a mildly positive DCAD diet. Urine $\mathrm{pH}$ was not measured for the cows in the study, and the degree to which the DCAD diets induced a metabolic acidosis is unknown. The use of a lower DCAD diet capable of causing a compensated metabolic acidosis has been shown to create a marginal increase in the blood ionized $\mathrm{Ca}$ pool (Charbonneau et al., 2006) and affect $\mathrm{Ca}$ turnover rates. A faster response to a sudden increase in Ca demands at parturition is thought to be improved during chronic acidotic states due to its influence on increased bone resorption (Block, 1984; Leclerc and Block, 1989), vitamin D metabolism (Gaynor et al., 1989; Goff et al., 2014), and a likely enhancement of tissue sensitivity to parathyroid hormone (Goff et al., 2014). A concomitant decrease in bone formation (van Mosel et al., 1993) and a hypercalciuric state are also observed during metabolic acidosis
(Grünberg et al., 2011). Overall, by feeding a negative DCAD, most cows can often maintain higher turnover rates of $\mathrm{Ca}$ that can help alleviate hypocalcemia following parturition.

Parity was also a significant predictor of SCH classification at calving. Increased age is known to impair $\mathrm{Ca}$ metabolism; for instance, bone and intestine vitamin D receptors decline with aging (Horst et al., 1990). It is possible that second-lactation animals, as compared with older parities, are able to better maintain $\mathrm{Ca}$ turnover rates in the immediate postpartum period. Intriguingly, parity was not associated with the risk of SCH at 2 DIM. Subclinical hypocalcemia classification at calving and locomotion score of the animal were significant predictors of SCH at 2 DIM and demonstrated to interact. For normocalcemic animals at calving, being lame increased their risk of being classified as SCH at 2 DIM. Oetzel and Miller (2012) found that lame cows had an increased milk production response when treated with an oral $\mathrm{Ca}$ bolus. It is likely that with a pen change following parturition, lame cows may have additional feed intake issues associated with social turmoil that result in lower blood $\mathrm{Ca}$ concentrations. Animals that were lame and $\mathrm{SCH}$ at calving had the highest risk of being classified as SCH again at 2 DIM, as compared with normocalcemic, nonlame individuals, indicating that both risk factors act in a synergistic way. For nonlame animals, SCH classification at calving was also associated with an increased risk of $\mathrm{SCH}$ at 2 DIM, suggesting that animals with a negative $\mathrm{Ca}$ 
balance at parturition can carry over that status to at least 2 DIM.

Retained placenta tended toward an association with $\mathrm{SCH}$ at 2 DIM. Retained fetal membranes is a condition associated with impaired immune function and has been shown to be exacerbated by hypocalcemia (Kimura et al., 2002) due to a reduction in intracellular levels of $\mathrm{Ca}$ in polymorphonuclear cells (Kimura et al., 2006) and a decline in neutrophil phagocytic activity (Kimura et al., 2002; Martinez et al., 2012).

Our data set did not indicate that hyperketonemia in the prepartum period was associated with SCH at parturition. Unfortunately, fatty acids were not measured as they are a better marker to identify animals with a compromised energy balance in the prepartum than BHB (Ospina et al., 2010). Moreover, fatty acids and $\mathrm{BHB}$ do not correlate well in the periparturient cow (McCarthy et al., 2015a). Martinez et al. (2012) found a significant difference in fatty acid concentrations between normocalcemic and hypocalcemic animals from 0 to 7 DIM, although BHB was only different starting at 1 DIM. Larger data sets evaluating the relationship of fatty acids and $\mathrm{Ca}$ in the prepartum are warranted to further evaluate whether a negative Ca or energy balance may precede or exacerbate the other.

\section{CONCLUSIONS}

We were able to define a Ca threshold $(\leq 2.4 \mathrm{mmol} / \mathrm{L})$ for identification of prepartum animals more likely to be SCH at calving. Herd-level studies using this cut-point might be able to set targets to measure the success of preventative strategies. Further studies using longitudinal data sets are warranted to determine how the timing of blood sampling relative to calving and the use of different cut-points for SCH classification can better predict negative health and production outcomes, as different risk factors were found to be relevant at the evaluated time points.

\section{ACKNOWLEDGMENTS}

This study was funded primarily by Boehringer Ingelheim Vetmedica Inc. (St. Joseph, MO) as part of the Student Bovine Research Assistantship, with additional support by the President's Council of Cornell Women Affinito-Stewart grant. The authors also thank the participating herds, the Cornell Animal Health Diagnostic Center Clinical Pathology technicians, and a special thanks to Kathryn Bach, Anne Borkowski, Kaitlyn Briggs, Danielle Harris, Jamie Horstmann, Isabelle Louge, Morgan Robinson, Charlene Ryan, and
Claira Seely (Cornell University, Ithaca, NY) for their valuable time and efforts during data collection.

\section{REFERENCES}

Block, E. 1984. Manipulating dietary anions and cations for prepartum dairy cows to reduce incidence of milk fever. J. Dairy Sci. 67:2939-2948.

Chapinal, N., M. E. Carson, S. J. LeBlanc, K. E. Leslie, S. Godden, M. Capel, J. E. Santos, M. W. Overton, and T. F. Duffield. 2012. The association of serum metabolites in the transition period with milk production and early-lactation reproductive performance. J. Dairy Sci. 95:1301-1309.

Charbonneau, E., D. Pellerin, and G. R. Oetzel. 2006. Impact of lowering dietary cation-anion difference in nonlactating dairy cows: A meta-analysis. J. Dairy Sci. 89:537-548.

Fatemi, S., E. Ryzen, J. Flores, D. B. Endres, and R. K. Rude. 1991. Effect of experimental human magnesium depletion on parathyroid hormone secretion and 1,25-dihydroxyvitamin D metabolism. J. Clin. Endocrinol. Metab. 73:1067-1072.

Gaynor, P. J., F. J. Mueller, J. K. Miller, N. Ramsey, J. P. Goff, and R. L. Horst. 1989. Parturient hypocalcemia in Jersey cows fed alfalfa haylage-based diets with different cation to anion ratios. J. Dairy Sci. 72:2525-2531.

Goff, J. P. 2008. The monitoring, prevention, and treatment of milk fever and subclinical hypocalcemia in dairy cows. Vet. J. 176:50-57.

Goff, J. P., A. Liesegang, and R. L. Horst. 2014. Diet-induced pseudohypoparathyroidism: A hypocalcemia and milk fever risk factor. J. Dairy Sci. 97:1520-1528.

Grünberg, W., S. S. Donkin, and P. D. Constable. 2011. Periparturient effects of feeding a low dietary cation-anion difference diet on acidbase, calcium, and phosphorus homeostasis and on intravenous glucose tolerance test in high-producing dairy cows. J. Dairy Sci. 94:727-745.

Horst, R. L., J. P. Goff, and T. A. Reinhardt. 1990. Advancing age results in reduction of intestinal and bone 1,25-dihydroxyvitamin D receptor. Endocrinology 126:1053-1057.

Hosmer, D. W. J., S. Lemeshow, and R. X. Sturdivant. 2013. Applied Logistic Regression. 3rd ed. Wiley, Hoboken, NJ.

Kimura, K., J. P. Goff, M. E. Kehrli Jr., and T. A. Reinhardt. 2002. Decreased neutrophil function as a cause of retained placenta in dairy cattle. J. Dairy Sci. 85:544-550.

Kimura, K., T. A. Reinhardt, and J. P. Goff. 2006. Parturition and hypocalcemia blunts calcium signals in immune cells of dairy cattle. J. Dairy Sci. 89:2588-2595.

Lean, I. J., P. J. DeGaris, D. M. McNeil, and E. Block. 2006. Hypocalcemia in dairy cows: Meta-analysis and dietary cation anion difference theory revisited. J. Dairy Sci. 89:669-684.

Leclerc, H., and E. Block. 1989. Effects of reducing dietary cationanion balance for prepartum dairy cows with specific reference to hypocalcemic parturient paresis. Can. J. Anim. Sci. 69:411-423.

Martinez, N., C. A. Risco, F. S. Lima, R. S. Bisinotto, L. F. Greco, E. S. Ribeiro, F. Maunsell, K. Galvao, and J. E. Santos. 2012. Evaluation of peripartal calcium status, energetic profile, and neutrophil function in dairy cows at low or high risk of developing uterine disease. J. Dairy Sci. 95:7158-7172.

McCarthy, M. M., S. Mann, D. V. Nydam, T. R. Overton, and J. A. McArt. 2015a. Short communication: concentrations of nonesterified fatty acids and beta-hydroxybutyrate in dairy cows are not well correlated during the transition period. J. Dairy Sci. 98:62846290.

McCarthy, M. M., T. Yasui, C. M. Ryan, G. D. Mechor, and T. R. Overton. 2015b. Performance of early-lactation dairy cows as affected by dietary starch and monensin supplementation. J. Dairy Sci. 98:3335-3350.

NRC. 2001. Nutrient Requirements of Dairy Cattle. 7th rev. ed. Natl. Acad. Press, Washington, DC. 
Oetzel, G. R., and B. E. Miller. 2012. Effect of oral calcium bolus supplementation on early-lactation health and milk yield in commercial dairy herds. J. Dairy Sci. 95:7051-7065.

Ospina, P. A., D. V. Nydam, T. Stokol, and T. R. Overton. 2010 Evaluation of nonesterified fatty acids and beta-hydroxybutyrate in transition dairy cattle in the northeastern United States: Critical thresholds for prediction of clinical diseases. J. Dairy Sci. 93:546-554.

Reinhardt, T. A., J. D. Lippolis, B. J. McCluskey, J. P. Goff, and R. L. Horst. 2011. Prevalence of subclinical hypocalcemia in dairy herds. Vet. J. 188:122-124.

Sansom, B. F., R. Manston, and M. J. Vagg. 1983. Magnesium and milk fever. Vet. Rec. 112:447-449.

Sprecher, D. J., D. E. Hostetler, and J. B. Kaneene. 1997. A lameness scoring system that uses posture and gait to predict dairy cattle reproductive performance. Theriogenology 47:1179-1187.
Tatone, E. H., J. L. Gordon, S. J. LeBlance, and T. F. Duffield. 2015. Evaluation of a handheld device for measurement of $\beta$-hydroxybutyrate concentration to identify prepartum dairy cattle at risk of developing postpartum hyperketonemia. J. Am. Vet. Med. Assoc. 246:1112-1117.

van de Braak, A. E., A. T. van't Klooster, and A. Malestein. 1987. Influence of a deficient supply of magnesium during the dry period on the rate of calcium mobilisation by dairy cows at parturition. Res. Vet. Sci. 42:101-108.

van Mosel, M., A. T. van't Klooster, F. van Mosel, and J. van der Kuilen. 1993. Effects of reducing dietary $[(\mathrm{Na}++\mathrm{K}+)-(\mathrm{Cl}-+$ $\mathrm{SO} 4=)$ ] on the rate of calcium mobilisation by dairy cows at parturition. Res. Vet. Sci. 54:1-9.

Zou, G. 2004. A modified poisson regression approach to prospective studies with binary data. Am. J. Epidemiol. 159:702-706. 